\title{
The Soviet Version of Modernity: Weberian and Post-Weberian Perspectives
}

\author{
Mikhail Maslovskiy \\ Doctor of Sociological Sciences, Leading Research Fellow, Sociological Institute of FCTAS RAS \\ Address: 7th Krasnoarmeiskaya Str., 25/14, Saint Petersburg, Russian Federation 190005 \\ E-mail: maslovski@mail.ru
}

\begin{abstract}
The article discusses several approaches to the study of Soviet society drawing on Max Weber's theoretical models or following a broadly-understood Weberian tradition in historical sociology. Weberian perspectives have been used for the analysis of the Russian Revolution of 1917 and its aftermath. The early Bolshevik Party has been characterized as a community of "ideological virtuosi" while its further development has been described either as "incomplete rationalization" or as a re-traditionalization. In the article, it is argued that employing the post-Weberian multiple modernities approach allows us to overcome some of the difficulties that have emerged in this case. In particular, the article focuses on Johann Arnason's analysis of the Soviet model of modernity. For Arnason, the Soviet model incorporated both the legacy of imperial transformation from above and the revolutionary vision of a new society. He claims that communism represented a distinctive version of modernity rather than a deviation from the modernizing mainstream. In recent historical studies of the Soviet period, two approaches have been formed stressing the modernity of the Soviet regime or its neo-traditionalist aspects. The distinction between these approaches has been discussed by Michael David-Fox. The article considers the parallels between the new historical studies of Soviet society, on the one hand, and both Weberian and post-Weberian sociological perspectives, on the other.
\end{abstract}

Keywords: Max Weber, historical sociology, Johann Arnason, communism, modernity, Soviet society

\section{Introduction}

The international Weber renascence and a new wave of historical sociology represented important developments in world sociology since the 1970s. It has been argued that Weber's works can be examined "in a manner that clarifies their present-day utility to comparative-historical sociologists" (Kalberg, 1994: 3). Two main research strategies have been used in Weberian historical sociology. On the one hand, Weber's own concepts were employed, though these concepts could be systematized and modified. On the other hand, new theoretical approaches were used that followed a broadly understood Weberian tradition in historical sociology. In the latter case, concepts borrowed from other theoretical traditions could be employed, and new ideal types could be constructed. However, it should be noted that there were no attempts of a comprehensive analysis of 
Soviet communism from a Weberian perspective that could be compared to Weber's own studies of the economic ethic of world religions. At the same time some aspects of the development of Soviet society were considered by historical sociologists who drew on Weberian theory in their research.

The first part of the article discusses the approaches to the study of the Soviet system based on the concepts of Weber's sociology. In particular, the first part evaluates the works of Stefan Breuer and Klaus-Georg Riegel, both offering Weberian analyses of Soviet communism. The second part considers the post-Weberian multiple modernities approach to Soviet-type societies as elaborated by Johann Arnason. It is argued that this approach allows us to overcome some contradictions connected with the use of Weberian perspectives. Finally, the third part presents an account of recent debates on modernity and neo-traditionalism in Soviet society in the works of historians. It is emphasized that common points can be found in sociological and historical studies of the Soviet version of modernity.

\section{Weberian Approaches to Communism}

The Russian Revolution of 1917 and the early Soviet system have been discussed from a Weberian theoretical perspective by Stefan Breuer, who demonstrates the relevance of Weber's analysis of communism for understanding the revolution and its consequences. Weber distinguished three basic types of communism; the household communism of a traditional family, military communism, and finally, the communism of a religious group (1978: 153). These forms belonged mostly to pre-modern societies, but examples could also be found in modern times. Thus, in his articles on the Russian Revolution of 1905, Weber referred to the Russian peasant commune as the last remnant of communism in Europe. He described the clash between the institutions and values of modern capitalism and the archaic communism of the Russian peasantry (Weber, 1995).

Drawing on Weber's concepts, Breuer analyzes not only this type of agrarian communism but also the communism of the revolutionary army and the communism of the Russian intelligentsia. According to Breuer, all three forms played an important role in the Russian Revolution of 1917. At the same time, he tends to diminish the significance of peasant communism in favor of the other two forms. For Breuer, "the comradeship communism of the rebellious army" played a smaller part in the revolutionary events than Weber had believed since "the charismatic bands of followers of the Revolution's initial period were quickly transformed into a well-disciplined mass army" (1992: 270-271). The third form of communism discussed by Weber was represented by the utopian communism of the intelligentsia. However, in Breuer's view, Weber underestimated the role of this form in the Russian Revolution; his attitude to the Bolsheviks was based on the conviction that history "had never produced a single instance where intellectuals had actually brought down a state and then reconstructed it according to their own ideas" (Ibid.: 272). 
Unlike Weber, Breuer regards the Soviet political regime as a form of legitimate domination. Breuer believes that the concept of charismatic domination is relevant in this case, although he singles out not the personal qualities of the revolutionary leaders but rather the impersonal charisma of the Bolshevik party as a community of "ideological virtuosi." This concept that draws on the Weberian notion of religious virtuosi was originally used by Roth (1984) for the analysis of countercultural movements of the 196os. In addition, Breuer refers to the concept of charisma of reason which was applied by Weber to the 1789 French Revolution. For Weber, the charismatic glorification of reason by Robespierre represented "the last form that charisma has adopted in its fateful historical course" (1978: 1209). However, in Breuer's view, this form of charisma distinguished not only the French Jacobinism, but other revolutionary movements including Bolshevism. While he acknowledges the differences between these movements, Breuer also finds common features of Jacobinism and Bolshevism, such as the belief that society could only be changed by revolutionary means, preference for centralized and statist organizational forms, and the fetishization of revolutionary ideology (1992: 279).

Some parallels can be found between Breuer's analysis and Eisenstadt's approach to Jacobin ideology. For Eisenstadt, Jacobinism set the paradigm for revolutionary transformations of modernity. The essence of the Jacobin program was the belief in the transformation of society through political action: "The pristine Jacobin orientations and movements have been characterized by a strong predisposition to develop not only a totalistic world-view, but also over-arching totalitarian all-encompassing ideologies, which emphasize a total reconstitution of the social and political order" (Eisenstadt, 1999: 73). According to Eisenstadt, the Jacobin component could be found in different political forms but they developed first in "leftist" revolutionary movements "which often conflated the primacy of politics with the implementation of a technologic or moralistic vision of progress and reason" (Ibid.).

Breuer argues that the Bolshevik regime that tried to reconstruct the whole society according to a rational plan could be considered as the embodiment of charisma of reason. He emphasizes the rational features in the Soviet system although, as he acknowledges, the Bolshevik type of rationalization "remains strangely incomplete" (1992: 284). Breuer analyzes the early Bolshevik government and provides a general account of the Soviet system as a whole. He does not discuss the character of the Stalinist regime in the USSR in detail. This seems to be paradoxical since most researchers representing different schools in Soviet studies regarded Stalin's "revolution from above" as the decisive moment in formation of the Soviet system (Tucker, 1992; Fitzpatrick, 1999). This decisive moment has been practically ignored in Breuer's analysis. Apparently, the Stalinist dictatorship hardly fits into his theoretical scheme.

On the other hand, Breuer tries to explain the reasons for an incomplete Soviet rationalization in the post-Stalinist period. He refers to Weber's analysis of the tendency towards bureaucratic autonomization. As Breuer points out, bureaucracies which escape from political control and pursue their own interests "treat offices as sinecures, monopolize the leading positions for functionary advancement, develop a pronounced 'guild' 
mentality, and allow other factors besides purely technical qualifications to enter into appointment decisions" (1992: 284). Thus, Breuer takes some unintended consequences of the Bolshevik project into consideration. Nevertheless, his main focus is on the early stage of implementation of the project. Apparently, Breuer's analysis should be supplemented with other approaches to the Soviet system.

A Weberian account of the evolution of the Bolshevik party has also been offered by Klaus-Georg Riegel. It is characteristic that, like Breuer, he starts with the notion of "ideological virtuosi" but he makes some conclusions that are altogether different. Riegel focuses on a comparative analysis of religious communities and revolutionary organizations. He claims that the evolution of religious communities and particularly monastic orders offers a possibility of a comparison between secular communities of virtuosi and their religious predecessors (Riegel, 2002: 112). For Riegel, in spite of the obvious differences in the purposes of their activities, religious and secular communities of virtuosi possess some similar structural characteristics.

Riegel devotes special attention to the "confession rituals" in the revolutionary parties. In his micro-sociological analysis of such rituals in the Bolshevik party, this scholar draws not only on Weberian theoretical models but also on some ideas of Durkheim and Foucault. He discusses the transition of the Bolshevik party as a community of "ideological virtuosi" into a "hierocracy" under Stalin, drawing a parallel with Weber's account of the rise of professional priesthood. For Weber, the emergence of a church is accompanied by the rationalization of dogma and rituals. Accordingly, the Holy Scriptures are provided with commentaries and then turned into objects of systematic education. At the same time, the personal charisma of the virtuosi is substituted with the charisma of office while the administrative apparatus with disciplined functionaries is formed (Ibid.: 117).

Riegel considers Marxism-Leninism as a kind of political religion. As he argues, the Leninist cult, which was already established during his lifetime, "laid the foundations for a political and sacral tradition which could be selectively used by the Stalinist hierocratic power" (Riegel, 2005: 109). For Riegel, the formation of Stalin's "hierocracy" included a selective reformulation of the Leninist legacy. Riegel claims that the new "sacral tradition" was invented by "ideological experts" of Stalinist orthodoxy. He writes: "The most important tenet of faith in this invented sacral tradition of Marxism-Leninism was that Stalin alone qualified as the only true disciple of Lenin; the consequence thus being his monopoly of infallible interpretation of his holy scriptures" (Ibid.: 110).

In Riegel's view, the traits of "hierocracy" were particularly conspicuous in the party purges of the late 1930s, but it should be taken into account that only an analogy between the Bolshevik regime and the system of hierocratic domination can be discussed. This analogy can be really convincing, as Riegel's analysis of Stalinist "criticism and selfcriticism" demonstrates. Nevertheless, crucial differences exist between political and hierocratic domination. Overall, Riegel's analysis can be seen as complementary to other Weberian approaches, but it does not allow us to provide a detailed account of the Soviet political regime. 
It seems that the concept of artificially-produced charisma could also be relevant for such an account. According to Weber, charisma can be "a gift that inheres in an object or person simply by virtue of natural endowment" but charisma may also "be produced artificially in an object or person" (1978: 400). While genuine charisma was characteristic of religious prophets and founders of empires, charisma is manufactured with the use of the mass media in modern political life. The concept of manufactured charisma has been applied to fascist regimes. Thus, the rise of Mussolini and Hitler "whose biography prior to their entry into politics is rather pale and below average" was due to artificially produced charisma (Breuer, 2008: 22). Apparently, this also applies to Stalin.

In the Soviet case, one could speak of a clash between the impersonal charisma of reason of the "old Bolsheviks" and the largely manufactured Stalin's personal charisma in the second half of the 1920s. By the middle of the 1930s, the emphasis was shifted from the manufacturing of personal charisma to the invention of the new tradition (Maslovskiy, 2016: 27). This culminated in the 1938 publication of the Stalinist "holy scripture," The Short Course of History of the All-Union Communist Party. This book, published at the end of the Great Purge, "gave the charismatic leadership a traditional basis through a mythical account of party history" (Arnason, 1993: 111).

At first sight, the approaches elaborated by Breuer and Riegel seem to be incompatible. While Breuer emphasizes the modernizing and rationalizing features of Bolshevism, Riegel focuses on its largely non-modern structural and ideological traits. Nevertheless, both approaches reflect some essential characteristics of the Soviet political regime, particularly of the 1920 and 1930s. It can be argued that they consider different aspects of the Bolshevik project and some unintended consequences of its transformation. Apparently, the gap between these approaches can be bridged on the bases of the multiple modernities perspective in contemporary historical sociology.

\section{The Soviet Model from the Multiple Modernities Perspective}

The multiple modernities perspective in sociological theory was originally developed by Shmuel Eisenstadt and elaborated by Johann Arnason, Peter Wagner, and other scholars. While Eisenstadt's contribution first of all consists of the analysis of Axial Age civilizations, his discussion of multiple modernities is particularly relevant for contemporary sociology (Eisenstadt, 2001). His multiple modernities theory has been characterized by Spohn as "a crucial alternative to the revived mainstream (neo)-modernization paradigm, the predominant modes of globalization analysis as well as the socio-philosophical discourse on modernity and postmodernity" (2001: 499-500). At the same time, as Peter Wagner claims, Eisenstadt's approach "has failed to make the innovative impact that one could have expected" (2010: 54). According to Wagner, Eisenstadt's strong idea of "cultural programme" can be applied to "classical" civilizations, but not so much to contemporary versions of modernity.

Johann Arnason's multiple modernities perspective partly draws on Eisenstadt's theory and employs other sources, particularly Cornelius Castoriadis" theory of "social 
imaginaries." Arnason's works of the 1990 s and 2000 s have been characterized as "a mix of Weber and Castoriadis" (Blokker, Delanty, 2011: 120). According to Arnason, civilizational analysis in historical sociology as represented by Benjamin Nelson and Shmuel Eisenstadt can be regarded as "post-Weberian" (2003b: 228). This term can also be applied to Arnason's approach. In his works, Arnason focuses on social creativity and considers both the cultural and political aspects of the dynamics of civilizations and different types of modernity. It has been pointed out that Arnason's work represents “one of the most elaborate contributions to the contemporary revival of civilizational theory, methodology and analysis" (Spohn, 2011: 24). He has offered a theoretical model of civilizational analysis that includes various components which range from cultural premises to geographical contexts of civilizational patterns (Arnason, 2001).

Overall, the perspective of civilizational analysis proposed by Eisenstadt and elaborated by Arnason "begins with the recognition of the pluralistic nature of civilizations without any presupposition of a single model or the superiority of European civilization, which is seen as one of many" (Delanty, 2016: 24). In comparison with Eisenstadt, Arnason makes a stronger emphasis on interaction of civilizational patterns. For Arnason, civilizations should not be seen as "self-contained or self-generating" but are shaped by their interactions with other civilizations (Ibid.: 24-25). Arnason has been regarded as the main representative of the "relational" perspective within contemporary civilizational analysis (Smith, 2017: 29).

The theory of multiple modernities which developed within the paradigm of civilizational analysis presupposes that the concept of modernization as the transition from tradition to modernity is not sufficient for an understanding of the social and cultural dynamics of contemporary societies. From this perspective, "tradition" and "modernity" should not be regarded as mutually-exclusive concepts. At the same time, the variety of cultural and institutional forms of today's societies cannot be explained with only references to traditions. On the one hand, traditions provide cultural resources that influence the working out and realization of different projects of modernity. On the other hand, traditions themselves are being transformed and can be invented in the conditions of modernity. Unlike the more conventional theoretical approaches, Arnason's version of civilizational analysis emphasizes the heterogeneous, ambivalent, and antinomian character of civilizational patterns. The distinctive characteristic of this perspective is a focus on civilizational transformations and intercivilizational encounters (Braslavskiy, Maslovskiy, 2014: 48-49).

It is significant that Arnason has devoted considerable attention to the analysis of the Soviet "alternative" version of modernity. Arnason points out that there was a tendency to regard communist societies as "pre-, anti- or pseudo-modern" after the collapse of the Soviet system. However, he argues that these societies represented "a distinctive but ultimately self-destructive version of modernity rather than a sustained deviation from the modernizing mainstream" (Arnason, 2002: 61). First of all, Arnason focuses on the character of imperial modernization in Russia. In his view, the origins and the later transformation of the totalitarian project could only be understood with reference to 
that background (Arnason, 1993: 21). For Arnason, the Soviet model incorporated both the legacy of imperial transformation from above and the revolutionary vision of a new society. Their synthesis led to a "reunified and rearticulated tradition" which served "to structure a specific version of modernity" (Arnason, 2002: 87).

According to Arnason, both classical and contemporary approaches to modernization tended to underestimate the significance of imperial formations. Max Weber did not offer a detailed comparative analysis of imperial traditions, and, in subsequent literature, most of the attention was devoted to the contrast between traditional and modern states, while the specific characteristics of imperial states were not taken into account. However, Eisenstadt's study of the social and political structures of empires (Eisenstadt, 1993) demonstrated that "the mobilizing capacity of the imperial centre with regard to social forces and resources sets it apart from more traditional states" (Arnason, 1993: 19). Following Eisenstadt, Arnason claims that empires could be the vehicles of changes that pre-figure more radical trends of the modernization process.

In his comparative analysis of the origins of Soviet and Chinese communism, Arnason employs the concept of imperial revolution. He claims that the revolutions in the two collapsing empires ultimately led to the restoration of imperial structures on new foundations. As he notes, it is paradoxical that a revolutionary ideology borrowed from the West "served to rationalize and legitimize the innovative restoration of the two most powerful non-Western empires" (Arnason, 2003a: 309). Arnason focuses on the interaction and entanglements of imperial legacies and revolutionary processes in these two cases. He demonstrates some similarities between the two imperial revolutions. However, on the eve of the revolution, the Russian empire was a more active participant in "global rivalries" and had advanced much further along the path of reforms in comparison with its Chinese counterpart (Ibid.: 310).

Arnason also considers the difference between short-term and long-term perspectives of the Russian Revolution. As he points out, the culmination of the Bolshevik takeover was the end of the Civil War in 1921, while Stalin's "second revolution" that began at the end of the 1920s "was the final twist to the Bolshevik project" (Arnason, 2016: 29). The end of that "second revolution" can be seen in "the termination of the Great Purge in 1938 which "marks the self-destruction of the Bolsheviks and the final consolidation of a totalitarian regime" (Ibid.). Overall, Arnason believes that the comparative histories of revolutions should not emphasize either ideologies or power structures, but rather should employ an "interactive view." From this perspective, "intertwinings of culture and power should be seen as a fundamental feature of the social-historical world" (Ibid.: 41). At the same time, Arnason recognizes that a distinction should be made between historical situations "where acute power struggles predominate over everything else and others where concentrated expressions of ideological visions have the upper hand" (Ibid.). For Arnason, the first type is exemplified by the Russian Civil War, while the second type is represented by the Stalinist transformation from the end of the 1920 .

In his earlier study of the Soviet model, Arnason discusses the particular communist project of modernity which was rooted in Marxist theory and its more-marginal Bolshe- 
vik version connected to the Russian tradition. Like Riegel, Arnason regards MarxismLeninism as a political religion and claims that there was "a partial functional equivalence" between this ideology and traditional theological systems (1993: 116). Arnason emphasizes that the Soviet ideology continued both the scientific trend and "redemptive visions" in Marxism: "In the Bolshevik context, the result was simultaneous scientization and sacralization of the revolutionary project as well as of the vanguard to which it was entrusted, and both aspects were reinforced by the Russian background" (Ibid.: 117). Thus, Arnason overcomes the exclusive focus on either rationalizing or traditionalizing aspects of the Bolshevik regime represented respectively by Breuer's and Riegel's works.

In his analysis of the Soviet model of modernity, Arnason uses the concepts of Weberian political theory. For Arnason, Weber's typology of domination is the most convenient frame of reference for the study of the Soviet model, but it should not be regarded as an exhaustive inventory. Arnason makes a conclusion that while the Soviet mode of legitimization included elements of all three Weberian ideal types, it represented a new and original phenomenon nevertheless. Arnason distinguishes between two types of communist regimes; the charismatic variant leading to autocracy, and a more rationalized oligarchic one. He believes that "both charisma and rationality acquired specific meanings in the context of the Soviet model; their common denominator was a claim to authoritative knowledge and a mandate to program society on that basis" (Arnason, 2002: 74). While Arnason does not discuss this specific meaning of charisma and rationality in detail, there is a clear parallel between his approach and Breuer's more Weber-oriented analysis of "charisma of reason" and its transformation under Soviet communism.

According to Arnason, the Stalinist revolution from above realigned the Bolshevik project with older patterns of imperial modernization. At the same time, the slogan of "socialism in one country" justified the aims of the regime in the language of the world communist movement, while the idea of Leninism as the Marxism of a new epoch "gave the regime an ideological foundation for its claim to represent a new civilization with a global mission" (Arnason, 1995: 44). However, there were significant differences between "the pre-war and the post-war constellation." As Arnason points out, "the autocratic regime and the enlarged empire seemed to reinforce each other: Stalin's rule was re-legitimized by victory and expansion, and his charismatic leadership served to contain centrifugal trends within the bloc" (Ibid.: 46). On the other hand, the imperial legacy reemerged as a more independent factor after the "downgrading" of the totalitarian project. During the stage of "oligarchic stabilization," the Soviet system turned to global expansionism instead of internal mobilization (Arnason, 1993: 202). At this stage, "the global presence and prestige of the Soviet regime were clearly of major importance to its legitimizing effort at home" (Arnason, 2002: 79).

In his discussion of the period from the mid-1960s to the mid-1980s, Arnason distinguishes between two main trends in the dynamics of the Soviet regime; the internal one of re-traditionalization and the external one of globalization. While Arnason has referred to re-traditionalization as connected with the reactivation of the imperial legacy by the Stalinist regime, he also discusses it "in a more conventional and comprehensive 
sense, and with the connotations of a process rather than a strategy" during the Brezhnev period (1993: 213). In his view, this trend was evident in the attempts to present the "Soviet way of life" as a specific tradition. But, according to Arnason, the trend towards retraditionalization did not lead to a sustainable civilizational pattern.

As Arnason notes, it has become a commonplace understanding that the Soviet model was a failure on all levels. Soviet economic institutions proved incapable of meeting the standards imposed by the capitalist states, while the political structure in the USSR was unable "to sustain a global contest with a more resourceful rival" and at the same time the inability to resist the appeal of Western popular culture and consumerism was "a fatal weakness" (Arnason, 1995: 45). However, he believes that the crisis in the end of the 1980 os was not the result of "all-round and unmitigated failure," but rather a "peculiar combination of limited success and long-term failure" (Ibid.: 46). It should be noted that the relevance of the multiple modernities perspective for understanding the causes of Soviet collapse has been considered by Richard Sakwa, who stresses that the Soviet experiment represented an attempt to create an alternative modernity, but "failed to sustain itself as a coherent social order" (2013: 74). As he puts it, the Soviet system was "not anti-modern, but mismodernized" (Ibid.: 75).

\section{New Historical Accounts of Soviet Modernity}

In recent historical studies of the Soviet system and particularly of the Stalinist period, two approaches have been identified which stress the modernity of the Soviet regime or its neo-traditionalist aspects. On the one hand, the modernity approach focuses on such phenomena as "planning, scientific organization principles, welfare-statism, and techniques of popular surveillance" (Fitzpatrick, 2000: 11). On the other hand, the neo-traditionalist approach concentrates on the "archaicizing" phenomena: "petitioning, patronclient networks, the ubiquity of other kinds of personalistic ties like blat, ascribed status categories, "court" politics in the Kremlin, the mystification of power" (Ibid.).

The distinction between "modernist" and "neo-traditionalist" approaches to Soviet history has been discussed by Michael David-Fox. He argues that different trends can be found within each of them, but the "modernists" tendency to stress projects and programs has left an opening for the "neo-traditionalists" to look for results rather than intentions and to emphasize unexpected consequences in the guise of Stalin-era retreats" (David-Fox, 2006: 539). At the same time, the American historians who followed the "modernist" approach were "implicitly" moving towards the sociological multiple modernities perspective represented in particular by Eisenstadt's works (Ibid.: 538).

David-Fox singles out the first generation of Soviet modernity scholarship of $1990 \mathrm{os}$ and 20oos. As he argues, this generation "tended to focus on transformational agendas and processes, especially the interventionist state, programs articulated by elites, and the shift in historical attitudes that animated them" (2015: 23). However, one of the shortcomings of this scholarship, according to David-Fox, was a lack of development of the comparative perspective on Soviet modernity. When this perspective was present, comparisons 
were made mostly with the Western states. An exception was Stephen Kotkin's analysis of illiberal modernities of the inter-war period that included Japan (Kotkin, 2001).

The neo-traditionalist interpretation of the Soviet social order emerged partly as a reaction to the modernity approach. One of the main points of the "neo-traditional" critique was that "Bolshevik projects met Russian reality to produce unexpected reincarnations of traditional societies" (David-Fox, 2015: 27). In this connection, David-Fox considers Terry Martin's "oft-quoted" statement: "Modernization is the theory of Soviet intentions; neo-traditionalism, the theory of their unintended consequences" (Martin, 2000: 175). Nevertheless, as David-Fox stresses, representatives of that camp equated modernity with western societies and did not accept the possibility of illiberal or nonwestern modernity. At the same time "defining tradition remains one of the most pressing issues for any conception of neo-traditionalism" (David-Fox, 2015: 27). It can be argued, however, that unlike the two above-mentioned historical approaches, the multiple modernities perspective in historical sociology provides the theoretical analysis of both "Soviet intentions" and unintended consequences of the Bolshevik project.

David-Fox refers to Getty (2013) as an example of difficulties with application of the concept of tradition in historical studies of the Soviet political regime. In his book, Getty describes a thousand-year-old political culture that "drove the practices of boyars and commissars alike" (David-Fox, 2016: 27). From this perspective, events from Russia's distant past are seen as directly analogous to those of the Soviet period. For David-Fox, Getty's work is exemplary among those who do not see modern traits in Russian history while conceiving a binary dichotomy between the modern and the traditional. As DavidFox notes, this "black-and-white division" is based on "a reading of Weber's ideal types, astonishing in its literal-mindedness, as if everything modern in governance could be seen as 'rational-bureaucratic' and as if everything before that was personalistic, traditional, and patrimonial" (Ibid.: 28). Evidently, Getty ignores the contributions of today's Weberian sociology, let alone the multiple modernities perspective. Moreover, his approach represents a step back in comparison with historians from the "neo-traditionalist" camp who do not reject the concept of modernity altogether.

It is noteworthy that David-Fox discusses some overlaps and convergences between the modernist and neo-traditionalist perspectives on Soviet history; he writes that "both agreed that the Soviet order to some extent mixed modern features with others, whether those were seen as traditional or distinctive, peculiarly Russian, specifically Soviet, or illiberal. Neither side completely denied either particularistic traits or comparative commonalities" (David-Fox, 2015: 38). In his view, the debate between the modernist and neo-traditionalist camps illuminates the need to go beyond conceptual frameworks that segregate "intentions and consequences, ideas and circumstances, political programs and social reality, above and below. Only the study of their interrelationships can lead out of the impasse created in the post-Soviet debate" (Ibid.: 45). It should also be noted that the distinction between modernist and neo-traditionalist interpretations of Soviet history reminds a discussion in Weberian sociology of the two possible ways of routinization of 
charisma: rationalization and traditionalization. However, historians of the Soviet period are mostly unaware of this discussion.

David-Fox considers some sociological approaches to the problem of Russian/Soviet modernity. As he argues, Peter Wagner's book Sociology of Modernity: Liberty and Discipline has been "unjustly ignored in the Russian field," like many other works on multiple modernities (David-Fox, 2015: 29). At the same time, David-Fox does not discuss Wagner's later works devoted to modernity as "experience and interpretation" (Wagner, 2008). While the American historian refers to Johann Arnason's thesis that Marxist-Leninist ideology limited the role of reflexivity in social life (David-Fox, 2015: 31), he does not take other aspects of Arnason's analysis of Soviet modernity into consideration.

Overall, David-Fox distinguishes between four perspectives on Russian/Soviet modernity that could be found mostly in English-language historical works of the last fifteen years. First, there is a trend to reject the concept of modernity in discussing Russian history, particularly the period from the 1850 os until the 1950s. The second perspective is a tendency to regard modernity as a unified phenomenon, and to concentrate on what Russia and the USSR had in common with other modern states. The third perspective draws on the works of Eisenstadt and his colleagues who argued that Soviet communism represented an alternative version of modernity. Finally, the fourth position, which also presupposes multiplicity of modernities, emphasizes their entanglement and interaction (David-Fox, 2016: 21).

David-Fox stresses the relevance of the concepts of "alternative" and "entangled" modernities for the field of Russian/Soviet studies. In his discussion of alternative modernity, he draws on Eisenstadt's theory and historical works dealing with Nazi Germany, Imperial Russia, and the USSR. As David-Fox argues, if one accepts "the possibility that there have been many differing forms of modernity - many rather than none, one, or two - then it follows that there has been a specific historical path in the Russian and Soviet case that is at once particular and connected to other modern forms" (Ibid.: 34 ). He believes that this perspective allows researchers to build on a legacy of historiographical tradition delineating the peculiar traits of imperial Russia in a broader European context. Thus David-Fox refers to Martin Malia's use of the plural form of the German term Sonderwege (special paths) which, in his view, anticipated the concept of multiple modernities (Ibid.: 35).

According to David-Fox, the notion of "alternative" Soviet modernity which is sometimes used in historical studies is compatible with the sociological theory of multiple modernities (2016:36). He also considers the concept of "failed modernity" which is connected to conceiving the Soviet system as an alternative modern form. In this connection, he poses the following question; "does regime change mean that an entire system, an alternative modernity, failed? Or could it be that other strands of a broader Russian/ Soviet modernity that straddled 1917 also survived 1991?" (Ibid.: 37).

In his discussion of "entangled modernities," David-Fox refers to the works of Therborn (2003) and Arnason (2003a). He emphasizes that from this perspective, modernity is not seen as a single systemic whole, but it is rather "broken up into its component ele- 
ments and conceived in terms of the interactions of those elements across space and time" (2016: 39). In his view, this approach allows one to draw a more differentiated picture of differing paces of change and cross-border entanglements in the political, economic, and cultural spheres. The American historian believes that combining the concepts of "alternative" and "entangled" modernities could be a promising avenue of research. Overall, though, David-Fox focuses mostly on the debate on modernity and neo-traditionalism in the works of historians. While he follows this debate very closely up to the present day, he does not consider some of the latest developments in sociological discussion of multiple modernities. It can be assumed that a more detailed analysis of recent trends, not only in historical but also in sociological literature, would contribute to a better understanding of the peculiarities of the Soviet version of modernity.

\section{Conclusion}

Weberian perspectives on Soviet modernity tended to emphasize either the rational character of the Bolshevik project or re-traditionalizing trends as unintended consequences of that project. While the original Bolshevik project and the early Soviet regime have been discussed by Breuer as a specific case of rationalization, the Stalinist system apparently demonstrated traditionalist features, as highlighted by Riegel. At the same time, the routinization of "charisma of reason" in a neo-traditionalist direction is hard to explain within the framework of Weberian sociological theory. It seems that, in this case, Weber's theoretical models should be supplemented with elements of other theoretical approaches. It has been argued in the article that drawing on the "post-Weberian" multiple modernities perspective in historical sociology allows us to overcome some of the difficulties with the application of Weber's concepts to Soviet history.

Arnason's analysis of the Soviet model takes the interactions and entanglements of several traditions, both inherited from the pre-revolutionary past and invented ones, into consideration. As Arnason argues, the Bolsheviks followed a strategy of revolutionary transformation from above which included elements of the older project of imperial modernization. At the same time, the civilizational component of Soviet modernity was defined by Marxism-Leninism as a world political religion. Finally, the trend to retraditionalization during the last decades of the Soviet period was connected with the emergence of the "Soviet way of life" on the level of everyday behaviour. All of these (neo) traditional elements are discussed in their relationship with the strategies of the political elite. Cultural encounters with the West are also seen as increasingly important. Overall, Arnason's analysis is more nuanced and complex than references in the works of historians from the "neo-traditionalist" camp to Soviet "reincarnations" of traditional society as opposite to western-style modernity.

Apparently, there are some common points between the "modernist" approach to Soviet history and the theory of multiple modernities. As David-Fox demonstrates, representatives of this approach were "implicitly" moving towards the sociological multiple modernities perspective. However, what is needed is the transcending of the disciplinary 
boundaries between history and sociology. On the one hand, historians generally do not use the conceptual tools of historical sociology. On the other hand, historical sociologists often employ abstract theorizing without sufficient attention to empirical data. The field of Soviet studies could benefit from working out middle-range sociological theories that would be more empirically-oriented than the current multiple modernities perspective. Overall, combining Weberian and post-Weberian sociological perspectives and new historical approaches may result in a more comprehensive analysis of the Soviet system as a specific type of modern society.

\section{References}

Arnason J. (1993) The Future that Failed: Origins and Destinies of the Soviet Model, London: Routledge.

Arnason J. (1995) The Soviet Model as a Mode of Globalization. Thesis Eleven, vol. 41, no 1, pp. 36-53.

Arnason J. (2001) Civilizational Patterns and Civilizing Processes. International Sociology, vol. 16, no 3, pp. 387-405.

Arnason J. (2002) Communism and Modernity. Multiple Modernities (ed. S. Eisenstadt), London: Transaction, pp. 61-90.

Arnason J. (2003a) Entangled Communisms: Imperial Revolutions in Russia and China. European Journal of Social Theory, vol. 6, no 3, pp. 307-325.

Arnason J. (2003b) East and West: From Invidious Dichotomy to Incomplete Deconstruction. Handbook of Historical Sociology (eds. G. Delanty, E. Isin), London: SAGE, pp. 220-234.

Arnason J. (2016) Revolutions, Transformations, Civilisations: Prolegomena to a Paradigm Reorientation. Revolutions and Social Transformations: Reflections and Analyses (eds. J. Arnason, M. Hrubec), Edinburgh: Edinburgh University Press, pp. 27-55.

Blokker P., Delanty G. (2011) Critical Theory, Modernity, Civilizations and Democracy: An Interview with Johann P. Arnason. European Journal of Social Theory, vol. 14, no 1, pp. 119-132.

Braslavskiy R., Maslovskiy M. (2014) Tsivilizatsionnyi analiz i sovetskii modern [Civilisational Analysis and Soviet Modernity]. Emergency Reserve: Debates on Politics and Culture, no 6, pp. 45-55.

Breuer S. (1992) Soviet Communism and Weberian Sociology. Journal of Historical Sociology, vol. 5, no 3, pp. 267-29o.

Breuer S. (2008) Towards an Ideal Type of Fascism. Max Weber Studies, vol. 8, no 1, pp. 11-47.

David-Fox M. (2006) Multiple Modernities vs. Neo-Traditionalism: On Recent Debates in Russian and Soviet History. Jahrbücher für Geschichte Osteuropas, vol. 54, no 4, pp. 535-555.

David-Fox M. (2015) Crossing Borders: Modernity, Ideology, and Culture in Russia and the Soviet Union, Pittsburgh: University of Pittsburgh Press. 
David-Fox M. (2016) Modernost” v Rossii i SSSR: otsutstvuiushchaia, obshshchaia, al'ternativnaia ili perepletennaia? [Russian-Soviet Modernity: None, Shared, Alternative or Entangled?], New Literary Observer, no 4, pp. 19-44.

Delanty G. (2016) A Transnational World? The Implications of Transnationalism for Comparative Historical Sociology. Social Imaginaries, vol. 2, no 2, pp. 17-33.

Eisenstadt S. (1993) The Political Systems of Empires, London: Transaction.

Eisenstadt S. (1999) Fundamentalism, Sectarianism and Revolution: The Jacobin Dimension of Modernity, Cambridge: Cambridge University Press.

Eisenstadt S. (2001) The Civilizational Dimension of Modernity: Modernity as a Distinct Civilization. International Sociology, vol. 16, no 3, pp. 320-340.

Fitzpatrick S. (1999) Everyday Stalinism: Ordinary Life in Extraordinary Time: Soviet Russia in the 1930s, Oxford: Oxford University Press.

Fitzpatrick S. (2000) Introduction. Stalinism: New Directions (ed. S. Fitzpatrick), London: Routledge, pp. 1-14.

Getty J. A. (2013) Practicing Stalinism: Bolsheviks, Boyars, and the Persistence of Tradition, New Haven: Yale University Press.

Kalberg S. (1994) Max Weber's Comparative-Historical Sociology, Cambridge: Polity Press.

Kotkin S. (2001) Modern Times: The Soviet Union and the Interwar Conjecture, Kritika: Explorations in Russian and Eurasian History, vol. 2, no 1, pp. 111-164.

Martin T. (2000) Modernization or Neo-traditionalism? Ascribed Nationality and Soviet Primordialism. Russian Modernity: Politics, Knowledge, Practices (eds. D. Hoffmann, Y. Kotsonis), Basingstoke: Macmillan, pp. 161-182.

Maslovskiy M. (2016) The Imperial Dimension of Russian Modernisation: A Multiple Modernities Perspective, Europe-Asia Studies, vol. 68, no 1, pp. 20-37.

Riegel K.-G. (2002) Ritualy ispovedi v soobshchestvakh virtuozov: Interpretatsiya stalinskoi kritiki i samokritiki s tochki zreniya sotsiologii religii Maksa Vebera [Confession Rituals in Communities of Virtuosi: Interpretation of Stalinist Criticism and Self-criticism from the Viewpoint of Max Weber's Sociology of Religion]. Journal of Sociology and Social Anthropology, vol. 5, no 3, pp. 108-129.

Riegel K.-G. (2005) Marxism-Leninism as a Political Religion. Totalitarian Movements and Political Religions, vol. 6, no 1, pp. 97-126.

Roth G. (1984) Charisma and the Counterculture. Max Weber's Vision of History: Ethics and Methods (eds. G. Roth, W. Schluchter), Berkeley: University of California Press, pp. 119-143.

Sakwa R. (2013) The Soviet Collapse: Contradictions and Neo-Modernisation. Journal of Eurasian Studies, vol. 4, no 1, pp. 65-77.

Smith J. (2017) Debating Civilisations: Interrogating Civilisational Analysis in a Global Age, Manchester: Manchester University Press.

Spohn W. (2001) Eisenstadt on Civilizations and Multiple Modernity: Review Essay. European Journal of Social Theory, vol. 4, no 4, pp. 499-508.

Spohn W. (2011) World History, Civilizational Analysis and Historical Sociology: Interpretations of Non-western Civilizations in the Work of Johann Arnason. European Journal of Social Theory, vol. 14, no 1, pp. 23-39. 
Therborn G. (2003) Entangled Modernities. European Journal of Social Theory, vol. 6, no 3, pp. 293-305.

Tucker R. (1992) Stalin in Power: The Revolution from Above, 1928-1941, New York: Norton.

Wagner P. (2008) Modernity as Experience and Interpretation. A New Sociology of Modernity, Cambridge: Polity.

Wagner P. (2010) Multiple Trajectories of Modernity: Why Social Theory Needs Historical Sociology, Thesis Eleven, vol. 100, no 1, pp. 53-6o.

Weber M. (1978) Economy and Society, Berkeley: University of California Press.

Weber M. (1995) The Russian Revolutions, Cambridge: Polity Press.

\title{
Советская версия модерна: веберианские и поствеберианские подходы
}

\author{
Михаил Масловский \\ Доктор социологических наук, ведущий научный сотрудник, Социологический институт РАН — филиал \\ ФНИСЦ РАН, Санкт-Петербург, Российская Федерация \\ Адрес: ул. 7-я Красноармейская, 25/14, Санкт-Петербург, 190005, Российская Федерация \\ E-mail: maslovski@mail.ru
}

В статье рассмотрены различные подходы к изучению советского общества, которые опираются на теоретические модели, разработанные Максом Вебером, либо следуют более широкой веберовской традиции в исторической социологии. Веберианские подходы применялись В том числе и для анализа Русской революции 1917 года и ее последствий. В частности, ранняя большевистская партия характеризовалась как сообщество «идеологических виртуозов», тогда как ее дальнейшее развитие описывалось как «незавершенная рационализация» либо ретрадиционализация. В статье подчеркивается, что использование поствеберианской концепции множественных модернов позволяет преодолеть некоторые сложности, возникающие в данном случае. Особое внимание уделяется в статье анализу советской модели модерна в работах Й. Арнасона. С точки зрения этого социолога, советская модель включала в себя как наследие имперской трансформации сверху, так и революционное видение нового общества. Как указывает Арнасон, коммунизм представлял собой особую версию модерна, а не отклонение от универсального пути модернизации. В то же время в исторических исследованиях советского периода сложились два подхода, выделяющие модернистский характер советского режима либо его неотрадиционалистские аспекты. Различия между этими двумя направлениями обсуждались в работах М. Дэвид-Фокса. В статье прослеживаются параллели между новыми историческими исследованиями советского общества и (пост)веберианскими социологическими подходами.

Ключевые слова: Макс Вебер, историческая социология, Йохан Арнасон, коммунизм, модерн, советское общество 